Article

\title{
Sustainable Consumption of Food: Framing the Concept through Turkish Expert Opinions
}

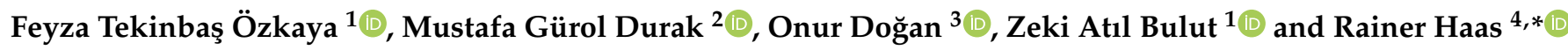 \\ 1 Department of Marketing and Foreign Trade, Izmir Vocational School, Dokuz Eylul University, \\ 35380 Izmir, Turkey; feyza.tekinbas@deu.edu.tr (F.T.Ö.); atil.bulut@deu.edu.tr (Z.A.B.) \\ 2 Department of Business Administration, Faculty of Business, Yaşar University, 35100 Izmir, Turkey; \\ gurol.durak@yasar.edu.tr \\ 3 Department of Management and Organization, Izmir Vocational School, Dokuz Eylul University, \\ 35380 Izmir, Turkey; onur.dogan@deu.edu.tr \\ 4 Department of Economic and Social Sciences, Institute of Marketing and Innovation, \\ University of Natural Resources and Life Sciences Vienna, 1180 Vienna, Austria \\ * Correspondence: rainer.haas@boku.ac.at; Tel.: +43-1-47-654-73516
}

check for updates

Citation: Tekinbaş Özkaya, F.; Durak, M.G.; Doğan, O.; Bulut, Z.A.; Haas, R. Sustainable Consumption of Food: Framing the Concept through Turkish Expert Opinions. Sustainability 2021, 13, 3946. https://doi.org/ 10.3390/su13073946

Academic Editor: Michael S. Carolan

Received: 2 March 2021

Accepted: 25 March 2021

Published: 2 April 2021

Publisher's Note: MDPI stays neutral with regard to jurisdictional claims in published maps and institutional affiliations.

Copyright: (c) 2021 by the authors. Licensee MDPI, Basel, Switzerland. This article is an open access article distributed under the terms and conditions of the Creative Commons Attribution (CC BY) license (https:/ / creativecommons.org/licenses/by/ $4.0 /)$.
Abstract: The scarcity of natural resources together with the exponentially increasing world population has made the sustainable consumption of food (SCF) a crucial issue, as it has impacts on a variety of environmental, health, economic, and social dimensions. Considering the rarity of a holistic view in previous studies, this study aims to assess the current situation in sustainable food consumption and develop suggestions from all aspects, depending on the opinions of experts. In this direction, semi-structured interviews are conducted with 25 experts from Turkey to frame the concept of SCF, reveal the level of consumers' awareness, and provide suggestions to support SCF implications. Experts have considered SCF from ecologic, social, economic, and health perspectives; ecologic aspects being the most important, followed by economic and social perspectives. Deficits on the consumer side are lack of awareness, unplanned shopping, and mistakes in post-consumption behavior. Lack of awareness about the consequences of meat production, difficulties in changing lifestyles and lack of motivation of adults were identified barriers to SCF. Finally, suggestions of the experts for achieving sustainability are mostly relevant to raising awareness on balanced nutrition and food waste, with the help of training programs and the efficient use of communication channels, such as social media.

Keywords: sustainable food consumption; food waste; consumer behavior; theoretical framework; sustainability

\section{Introduction}

Sustainability is a key concept for individuals, organizations and societies as well as future generations to survive. Thus, clarification of this concept, which is the aim of this study, becomes more important with the increase in world population. In line with this fact, the 2030 Agenda for Sustainable Development provides a global blueprint for dignity, peace, and prosperity for people and the planet, now and in the future. At its heart are the 17 Sustainable Development Goals (SDGs) as an urgent call to action by all countries-developed and developing-in a global partnership. The fact that food is the basic resource for life highlights the need for a comprehensive goal that can be achieved by reducing food waste, promoting healthy and balanced nutrition, raising awareness of the society on responsible food consumption and developing policies on food consumption by regulatory authorities in connection with ensuring the sustainability of food consumption. Therefore, ensuring sustainable food consumption can also be seen as a generic goal that can be supported by almost all SDGs. Among all SDGs that are related to food in the context of responsible consumption, SDG 12-Ensure sustainable consumption and production patterns-is the most relevant. 
According to the Sustainable Development Goals Report 2018, which was prepared by the United Nations [1], by 2018, 108 countries had national policies on sustainable consumption and production. People rely on such materials to meet basic needs for food, clothing, water, shelter, infrastructure, and many other aspects of life. Across much of the developing world, an increase in the material footprint is required to enhance the living standards of growing populations. At the same time, it is important to decrease reliance on raw materials and increase their recycling to reduce environmental pressure and impact [2]

In addition, SDG 2-Zero Hunger, SDG 3-Health, and SDG 4-Education can also be clearly associated with ensuring the sustainability of food consumption. It also constitutes a reference point for the achievement of SDG 2, as reducing food waste through sustainable food consumption will facilitate the fight against hunger and ensuring food security. At the same time, ensuring healthy lives and promoting well-being, which is the basis of SDG 3, is in a tight relationship with nutritional behaviors, which is a dimension of sustainable food consumption. Therefore, the components of sustainable food consumption such as balanced diet, conscious consumption and environmental protection will only be possible with the development and dissemination of effective education programs, raising universal awareness and realizing actions that will create behavioral change in people, thus supporting the goals of SDG 4.

Certainly, the sustainable consumption of food (SCF) is one of the most important issues of recent years. Over the last few years, many studies have revealed the dramatic view of food loss and waste for many countries and identified this as a global problem. Food consumption accounts for almost one-third of households' total environmental impact [3] and is thus of prime importance. These environmental impacts include climate change, soil degradation, water pollution, water scarcity, loss of habitats, and biodiversity. Food waste entails unnecessarily used resources, such as water, cropland, fertilizers, or fossil fuels, as well as greenhouse gas (GHG) emissions [4]. In the report of the Institute for Climate Economics, Rogissart et al. [5] estimated that GHG emissions from food consumption in 2010 were around $28 \%$ of global emissions with $13.8 \mathrm{GtCO} 2 \mathrm{e}( \pm 3.6 \mathrm{GteqCO} 2)$. Around $75 \%$ of GHGs are emitted during the production phase, $15 \%$ between the farm gate and the retail store, and 10\% after retail. Similarly, Sandström et al. [6] confirmed that the food consumption of European Union (EU-28) countries' citizens generated $540 \mathrm{MtCO} 2$ eq in 2010, including land-use changes. Barrett and Scott [7] suggested that GHG emissions can be reduced significantly through changes in the food sector. The European Commission [8] stated that the food sector was the cause of approximately $22 \%$ of global warming in Europe.

In terms of the total world population, in some regions people suffer from hunger and poor nutrition because of the inaccessibility of safe food and water $[9,10]$. On the other hand, in some other regions people are overweight or obese and still have an increasing tendency to dietary shifts toward more sugar, animal protein, and trans fats [11]. There are approximately 155 million overweight or obese children on this planet, whereas 148 million children are undernourished [12]. To achieve sustainability in food consumption, food security and food safety issues should be considered together for both underand over-consumption regions. Additionally, policymakers should pay more attention to complex interdependencies along the food chain and the complexities of modern global food systems [11].

There is also a moral aspect of the sustainable consumption of food because consumers are assumed to feel guilty or uneasy about wasting food [13-15]. However, in a recent study, Watson and Meah [16] report that consumers are not conscious of the environmental impacts of food waste, and only a few accept social impact as a reason for feeling guilty about their food waste. Additionally, the most important drivers for consumers that prevent food waste are found to be time and money. Nevertheless, food consumption is not only an environmental and economic problem but also a social and ethical one. According to Ayala [17], the perception of needs and desires; understanding of quality of life, progress, growth, and development in society; as well as cultural and ethical values, which are linked to consumption patterns, need to be emphasized. 
There are some indexes that evaluate the countries according to food sustainability indicators. One of these indexes is the Food Sustainability Index (FSI). The FSI ranks 67 countries in terms of the sustainability of food systems. Environmental, social, and economic performance indicators are the three key indicators of this index. This index, which evaluates this concept in the three categories of "food loss and waste," "sustainable agriculture," and "nutritional challenges," was formed by qualitative and quantitative evaluations of 38 indicators and 90 individual scales. France is in first place among 35 high-income countries in the 2018 edition of the FSI, followed by the Netherlands and Canada. In this index, Turkey is ranked as 58th out of 67 countries [18].

The sustainable consumption of food has become one of the key priorities of national strategies and policies. The 2013-2017 Strategic Plan of Ministry of Food, Agriculture and Livestock of Turkey identifies three main missions-ensuring access to safe food and high-quality agriculture products, which are demanded by Turkish and global markets; ensuring sustainable usage of agricultural and ecological resources; and determining and implementing policies to increase the standard of living in rural areas [19].

At this point, it is essential to reveal how sustainable consumption is perceived by experts who are related to SCF. The opinions and suggestions of the experts are so important and remarkable due to their impact and their leadership and regulatory roles in the field of SCF. Despite the existence of many prior studies, no study examines in a holistic approach the scope, dimensions, features, challenges, barriers, and strategies to promote the sustainable consumption of food. In particular, the concept was studied with many different angles. However, these studies have mostly investigated the various aspects of the concept from a consumer perspective. This situation points out the deficiency in revealing the perspectives and views of the experts in the field, which is another crucial aspect of the topic. It is believed that providing an in-depth explanation of sustainable food consumption can only be possible using a qualitative methodology. This study sets out to fill this gap and present the advantage of a suitable methodological framework by using qualitative research. Offering a comprehensive point of view by experts from various fields, such as academia, non-governmental organizations (NGOs), governmental bodies, and industry, will make the concept of SCF easier to understand and evaluate. Thus, this study aims to do the following: (i) explore all aspects of SCF to reveal a framework that considers a holistic perspective, (ii) discuss the details of each element for providing a theoretical foundation, and (iii) reveal the concept of SCF within the framework of consumers from the perspective of experts.

\section{Theoretical Background}

\subsection{Sustainable Development and Consumption}

The concept of sustainability is accepted as an important issue to examine by a variety of disciplines, such as economics, marketing, and environmental sciences. Nkamnebe [20] defines sustainability as " . . a global approach towards securing lasting welfare for the entire human race." It has primarily risen from environmental or ecological aspects, followed by economic, social, and political dimensions [21]. Within this framework, sustainable development represents development that meets the present needs without compromising the abilities of future generations to meet their needs [22]. However, it is possible only through the integration of environmental, economic, and social components of development [23]. In terms of sustainable development, sustainable solutions should protect social equity; respect cultural pluralism; be ecologically sound and economically viable; be based on science, which considers the material and non-material bases of life equally; adapt to technologic developments; and be designed to empower and develop human capacity and potential. Sustainable development aims to find a balance amongst these objectives [24]. With the widespread objectives and scope of sustainability, sustainable consumption is an important topic that has attracted much attention in research and industry.

In the marketing context, sustainable consumption is mostly discussed from economic and societal aspects. Wolff and Schönherr [25] define sustainable consumption as 
a socially and ecologically concerned way of buying, using, and disposing of goods and services. From a more comprehensive and analytical perspective, it covers the complex social, economic, and political drivers of global environmental change, including global climate change [26]. Thus, the focus is on a resource-efficient and low carbon economy. Lee [27] also suggests that ecological and socially responsible citizens make their private consumption decisions focusing on environmental concerns. Kymäläinen et al. [28] focus on Generation Z, the future consumers, and their habits relating to sustainable food consumption, and suggest that the consumption behavior in the future can be associated with large-scale global concerns relating to sustainability, intertemporal consumer choices and life cycle models. They found that the attitudes of younger generations towards sustainable food consumption came from their families and that their spontaneous lifestyles made it difficult to manage their food waste behaviors. Additionally, the economic factors, e.g., price, are found to be more important than the environmental aspects, so that studying their attitudes required a business perspective. According to Jones et al. [29], sustainable consumption requires an integrated approach including the individuals' consumption decisions, marketers' business policies, and authorities' supervision and monitoring. Finally, Balan [30] focuses on retailers' role in engaging consumers in sustainable consumption and states that retailers must accomplish consumers and shoppers during the entire chain from awareness creation to waste reduction. The retailers are supposed to have many effective tools to engage consumers in sustainability, such as merchandising techniques, assistance to consumers throughout the sales process, promotions, etc., in order to provide sustainable choices to consumers, staging shopping experiences that enable consumers to make sustainable choices, reshaping norms to foster sustainable consumption, etc. [30].

Although it is not explored and well defined yet, sustainable consumption has three main aspects: caring for the environment, considering the needs of future generations, and meeting basic needs wisely. In studies such as Vermeir and Verbeke [31], sustainability is explained with the combination of economic, ecological, and social aspects. Furthermore, from the consumers' point of view, sustainable consumption incorporates attitudinal, cognitive, and behavioral aspects. While attitudes, beliefs, and knowledge about food are suggested to influence the food consumption choices, according to Wongprawmas et al. [32], personality, social groups, and socio-cultural position of individuals cause differences in the effects these factors create on them. In other words, sustainable consumption practices cannot be assured only by the behavioral aspect; it also requires individuals' positive intention and deep commitment [33]. Thus, there is no exact consensus on the aspects of sustainable consumption in the existing literature.

\subsection{Sustainable Food Consumption: Concept, Aspects, Challenges, and Strategies}

In terms of the politics regarding sustainable consumption and production, food consumption is a major issue with its impact on the environment, individual and public health, social cohesion, and the economy. The sustainable consumption of food has been studied using various approaches. Some studies focused on meat consumption [34-37] and organic foods [38,39], while many others include environmental impact $[40,41]$ and nutrition and health [42-45]. Some others have studied psychosocial determinants [46,47] as well as challenges and barriers [11,48]. Food consumption behavior on an individual level is mostly affected by cultural traditions, norms, fashion, and physiological needs. Grunert and Juhl [49] found that environmentally concerned people are more likely to buy more sustainable foods. Similarly, Nguyen et al. [39] also state that consumers with greater environmental concern are more likely to engage in environmentally friendly behaviors. Additionally, personal experiences such as tastes, health, and exposures, such as the availability of foodstuff, are other determinants. Furthermore, affordability, time availability, and household decision-making are effective in food consumption choices. Wongprawmas et al. [32] have also researched the determinants of food consumption choice and classified the factors as biological determinants (e.g., hunger, appetite, and taste), psychological determinants (e.g., mood, stress, and guilt), physiological determinants (e.g., access, education, 
and time), social determinants (e.g., culture, family, and peers), and economic determinants (e.g., cost, income, and availability). In addition, restricted food, green consumption, local consumption, and meat and protein substitutes are the derived factors for sustainable food consumption [50]. In demographic characteristics of households' context, there are remarkable differences in terms of age as well as gender. For example, women tend to behave more sustainably [51-53]. In terms of age, there are controversial findings in the literature. For instance, Verain et al. [54] revealed that consumers with a less sustainable lifestyle are younger, while Azzurra et al. [51] found older people tend to be low-intensity consumers. Using these behavioral and demographic factors, some studies determined consumer typologies. De Barcellos et al. [55] identified consumer clusters of indifferents, environmentally conscious, or sustainability-oriented citizens, while Bulut et al. [56] classify consumers as "indifferents", "sustainability enthusiasts", or "sustainability pioneers".

One of the primary consumption areas that has the largest impact on the environment is food consumption, which creates almost one-third of households' total environmental impact [3]. A Life Cycle Assessment (LCA) defines the environmental impacts as an open loop with an approach called "cradle-to-grave." LCA is suggested to be associated with only environmental components such as emissions, resource consumption, and environmental and health impacts associated with processes, products, or activities over their entire life cycles $[57,58]$. Consumers' behaviors during the handling and preparation stages also cause environmental impacts, through storage, cooking, and dishwashing. In addition, consumers affect the environment with their nutrition styles and diets. It is proven by many researchers that consumers are either unaware of or underestimating the relationship between food consumption and climate change [59-63]. In the study of Truelove and Parks [62], a survey performed in the US found that only $10 \%$ have associated meat consumption with climate change. According to the study of Lea and Worsley [60], 22\% of respondents in Australia believe that it would provide an environmental benefit to consume less meat. Heiskanen et al. [64] highlighted the role of education to promote sustainable consumption. There is no doubt that nutrition lifestyle not only has an impact on our health but also on the health of the planet. However, these prior studies have focused on the impact of food consumption on the environment. They are limited in explaining the influence of consumers' knowledge and awareness on avoiding the unsustainable consumption of food.

As a measure of how consumers' activities affect the environment and sustainability from different aspects, knowledge of different types of footprints is important because footprints are the quantitative expressions of the appropriation of natural resources by humans [65]. Herva et al. [66] proposed the ecological and carbon footprints to be the most appealing indicators for enterprises. As an addition to this study, the OPEN: EU Project within the Seventh Framework Program has extended the integrated footprint family by adding the water footprint in collaboration with an environmentally extended multiregional input-output (MRIO) model [67]. The existing literature also accepts these three footprints (ecological, carbon, and water) as the most important indicators together with the energy footprint because they refer to four worldwide concerns over threats to human society: food security, energy security, climate security, and water security [68].

Apart from environmental issues, many factors are identified in the literature in terms of motives and barriers to the sustainable consumption of food. Nutrition, health consciousness, social identity, concern for farmers, ethical concerns, food security, perceived availability, store reputation, and concerns about animal welfare are among the factors that influence the purchase of sustainable products, whereas high prices, time limit, access, lack of information, trust in labelling, limited marketing communication, and unawareness of environmental impact are the main barriers [61,69-73]. More specifically, Sidali et al. [74] found five main motivations of consumers toward sustainable foods: ethical attributes, naturalness, health-related aspects, terroir, and innovation. On the other hand, Gorgitano and Sodano [75] defined three main obstacles: the rebound effect, the knowledge-action gap, and the behavior-impact gap, which are limiting the sustainable consumption of food. 
At the individual level, lack of planning and purchasing, shopping routines, and lack of knowledge about the storage, preparation, and reuse of food were defined as the major causes of the unsustainability of food $[15,76]$.

At this point, two broad behavioral strategies toward sustainable food consumption can be distinguished. The first strategy is to make sustainable product choices concerning the way the product is produced, such as organic, free-range, or fair-trade products. The second strategy is to choose sustainable dietary patterns concerning dietary composition, consumption curtailment, and reduced quantity within product categories such as reduced meat consumption [54]. In addition, consumer behavior is also affected by perceptual biases, such as the halo effect, where products that are perceived as ecological are also perceived as better in other aspects, such as nutrition, health, etc. For example, an eco-labeled product may not only taste better and have a smaller environmental impact than the nonlabeled alternative, but it is also perceived to be healthier [77]. This situation also reflects the fact that consumers may have limited factual knowledge about the environmental impact (footprint) of food [78]. Another bias is "compensatory green beliefs," according to which some consumers feel that every individual is entitled to a certain budget of resources, so that savings in some resources gives them the right to offset by consuming more of other resources (or increasing waste), within the limits of this budget. Combined with the "negative footprint illusion," this idea most likely causes consumers to engage in acts of green consumption without actually lowering their total environmental impact [41]. Despite the huge body of psychological, sociological, and anthropological literature about consumer behavior, there is still confusion about how to induce long-term behavior changes for a healthier and more sustainable lifestyle. Nudging consumers toward a more sustainable lifestyle seems to be promising, but it still needs more research for specific guidelines for practitioners $[79,80]$.

\section{Food Consumption in Turkey}

While the animal-based food consumption is at the center of the nutrition patterns in developed countries, according to Food and Agriculture Organization of the United Nations (FAO) [81], the consumption of grain and grain products is ranked as the most consumed food groups in Turkey. Additionally, red meat is consumed as the main source of animal protein in Turkey, especially lamp and beef. According to the Ministry of Agriculture and Forestry Agricultural Economic and Policy Development Institute (TEPGE) (2020), red meat consumption per capita in Turkey is lower than in developed countries. However, when the consumption of red meat in the last five years is examined, it shows that the annual consumption per person is increasing [82]. In addition, in terms of fruit consumption Turkish consumers do not eat sufficient amounts compared to developed countries, although Turkey is one of the leading fruit producers worldwide [83].

However, Turkey has a diverse consumption pattern, mostly depending on cultural, demographic and geographical aspects. Besides, Turkey still has significant changes in food consumption patterns in recent years. The most influential factors related to these changes are urbanization, migration to big cities, the rising share of women in the labor force, changes in socio-economic and demographic factors, developments in technology, and increased consumption of ready-made food. Especially the increase in female labor force triggered the transformation of consumption patterns towards ready-made foods. The changes experienced in recent years have also affected the eating habits of consumers and the demand for animal products over time due to changes in income level, purchasing power, and social status of the consumer. For example, as the income level has increased, carbohydrate foods have been replaced by protein foods, to some extent [84].

In terms of household expenditures, the food expenditures have gained a higher share day-by-day. Households spend $20.8 \%$ of their expenditures on food. However, this increase in spending resulted in increased food waste as well. As food waste is mostly generated at household level, consumer food waste is of major concern $[28,85,86]$. According to The United Nations Environment Programme (UNEP) report, Turkey has $93 \mathrm{~kg}$ waste per 
capita yearly, and this is about $30 \%$ more than the global average of $74 \mathrm{~kg}$ per capita of food wasted each year [81]. Out of all EU-27 countries, Luxembourg has the highest food waste at household level with $54.4 \mathrm{~kg}$ per capita, and the Netherlands has the lowest with $28.2 \mathrm{~kg}$, to put the Turkish food waste into context [85]. Similarly, the Food Sustainability Index (FSI) developed by the Barilla Centre for Food and Nutrition Foundation (BCFN), in cooperation with The Economist Intelligence Unit, ranks Turkey as 57th out of 67 countries considered [18]. France, the Netherlands and Canada are leading countries in this index. Russia, Bulgaria and the United Arab Emirates are ranked at the end [18].

In this context, the food sustainability scores of Turkish people are found to be relatively low compared to other countries, especially because of very low scores on food loss and waste. On the other hand, Turkey is ranked as 33rd with a more-than-average score in terms of the nutritional challenges dimension of FSI, with the sub-dimensions quality of life (32nd in 67), life expectancy (43rd in 67) and dietary patterns (47th in 67) [18].

\section{Materials and Methods}

The data for this study were collected as part of an EU Project, which focuses on changing adults' behavior toward the sustainable consumption of food. The data collection process was conducted by using a semi-structured interview format, which included related questions about SCF. The main data collection form consists of a set of questions relating to the definition of SCF, concepts and aspects of $\mathrm{SCF}$, knowledge and awareness of consumers about SCF, challenges and carriers in SCFs, and strategies and suggestions for SCF. The following questions were asked:

- How do you define the concept of SCF?

- Which dimension would you apply to evaluate the concept of sustainable food consumption?

- How much are adults aware and how much do they know about sustainable food consumption? Please answer this in respect to the knowledge and awareness of different social classes.

- What are (if any) the obstacles that hinder adults to change their food consumption habits?

- When you compare the recommendations for sustainable food consumption with everyday food consumption habits, where is the biggest discrepancy between recommended food consumption and actual food consumption? Or in other words, what food habit should consumers change first to have the biggest positive effect on sustainability?

- What are your suggestions to enhance the current food consumption habits of adults?

- What are your suggestions to adults to achieve sustainable food consumption; before purchase, during preparation and consumption and after consumption of food products?

- Which communication channels do you think are more effective in sharing information about sustainability and food?

These interview questions were formulated by the authors based on a literature review. Before they were finalized, the questions were also assessed by three academics, two food engineers, and two sustainability experts from the private sector. Two questions were revised according to their suggestions. In addition, interviewers were encouraged to be flexible about asking some additional open-ended questions to main questions. These follow-up questions and communication between interviewees and interviewers served to obtain answers about the concept in detail.

The snowball sampling method was used in this study. To contact the first participants from different areas and professions, various ways were followed. To select interviewees from academics and the civil sector, participant lists of conferences in the field of sustainable consumption and food were used. Academics and professionals from NGOs who attended these scientific meetings and presented their studies were invited via e-mail to join the study. To invite participants from the business and governmental sector, mostly different social media channels have been used. Their shared materials, such as photos, tweets, texts, etc., and their followers and networks were analyzed. Additionally, some social 
media tags related to sustainability and food, such as sustainable consumption, food consumption, etc., have been defined, and people who share content by adding these tags have been specified. They were reached via e-mail and social media messaging platforms and asked to join the research. In addition, national authorities on consumption and food from the Chamber of Food Engineers, the Ministry of Agriculture and Forestry, the Izmir Metropolitan Municipality, etc., were reached and interviewed. Once a participant had been interviewed, other related experts were asked by that participant to extend the sample. In total, 32 experts were invited to attend the study to answer the interview questions. Three of them did not answer, and four of them replied that they were not able to join the study. Interviews were conducted with 25 Turkish experts whose works or professions were linked to SCF. The expert panel includes seven academics, nine businesspeople, three civils, and six people from the state. The civils include two participant from NGOs, whose area of interest is to decrease/eliminate food waste and raising awareness for environmental issues. Additionally, an influencer who dedicates himself/herself to attracting the attention of many people on zero waste and sustainability issues is included as one of the civil participants. As we have selected sub-samples from four different professional areas, the sampling gives the opportunity to have a more comprehensive point of view. A diagram of the sampling process is shown in Figure 1.

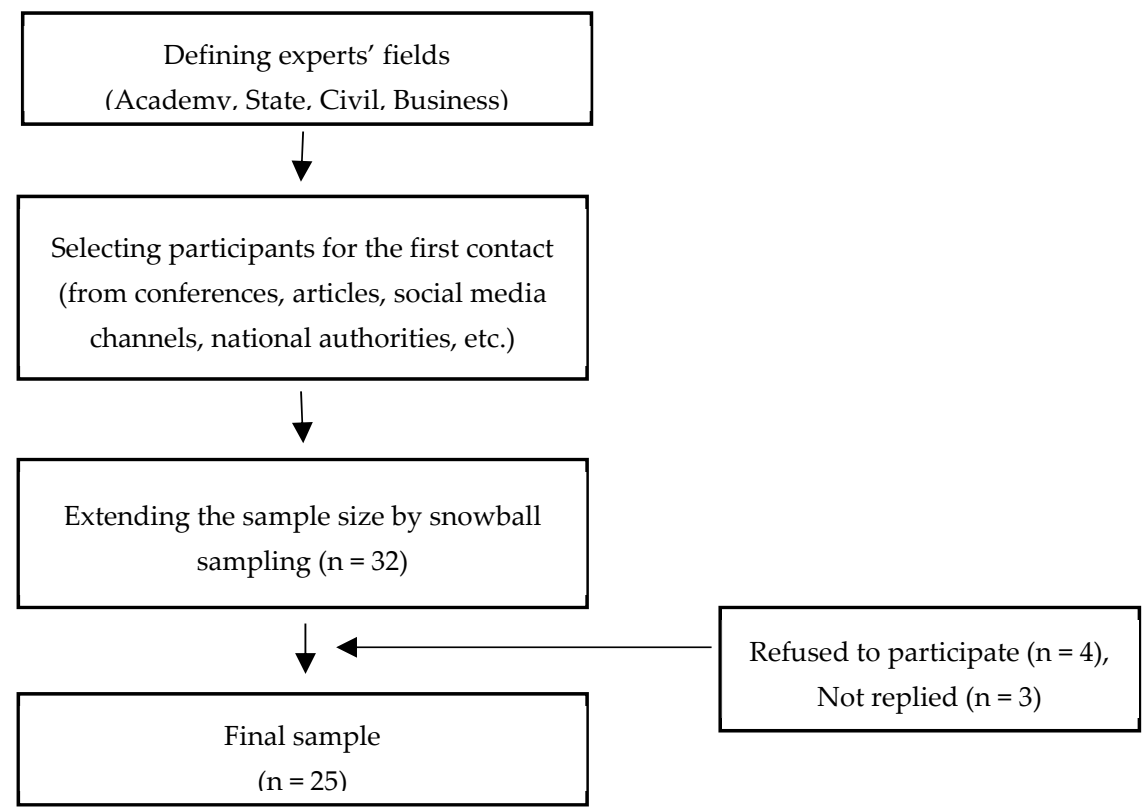

Figure 1. Diagram of Sampling Process.

Interviews were conducted in March and June 2019, mainly via face-to-face conversations, and a few interviewees were reached through video conferences and telephone calls. They were given general information about the research and their support was requested. The average duration of the interviews was $61 \mathrm{~min}$ (range 37-79 min). Detailed information about the experts and the interviews is presented in Table 1. 
Table 1. Characteristics of the Sample.

\begin{tabular}{|c|c|c|c|c|c|}
\hline Interviewee & Code & Gender & Age & Interview Type & Profession \\
\hline Academic 1 & P1 & $\mathrm{F}$ & 37 & Face-to-face & Marketing \\
\hline Academic 2 & P2 & $\mathrm{F}$ & 35 & Video Call & Food Engineer \\
\hline Academic 3 & P3 & $\mathrm{F}$ & 46 & Face-to-face & Environmental Engineer \\
\hline Academic 4 & P4 & M & 40 & Face-to-face & Food Engineer \\
\hline Academic 5 & P5 & M & 57 & Face-to-face & $\begin{array}{l}\text { Business and } \\
\text { Management }\end{array}$ \\
\hline Academic 6 & P6 & $\mathrm{F}$ & 41 & Telephone & Environmental Engineer \\
\hline Academic 7 & P7 & M & 40 & Telephone & Gastronomy \\
\hline Business 1 & P8 & $\mathrm{F}$ & 55 & Face-to-face & Consultant \\
\hline Business 2 & P9 & $\mathrm{F}$ & 39 & Face-to-face & Manager \\
\hline Business 3 & P10 & M & 42 & Face-to-face & Food Engineer \\
\hline Business 4 & P11 & $\mathrm{F}$ & 29 & Face-to-face & Dietitian \\
\hline Business 5 & P12 & M & 30 & Telephone & Food Engineer \\
\hline Business 6 & P13 & M & 49 & Face-to-face & Food Engineer \\
\hline Business 7 & P14 & M & 42 & Face-to-face & Dietitian \\
\hline Business 8 & P15 & M & 41 & Face-to-face & Dietitian \\
\hline Business 9 & P16 & M & 37 & Face-to-face & Dietitian \\
\hline Civil 1 & P17 & M & 28 & Face-to-face & Blogger and Influencer \\
\hline Civil 2 & P18 & M & 45 & Face-to-face & NGO's Agent \\
\hline Civil 3 & P19 & M & 41 & Face-to-face & NGO's Agent \\
\hline State 1 & $\mathrm{P} 20$ & $\mathrm{~F}$ & 39 & Face-to-face & Health Manager \\
\hline State 2 & P21 & M & 45 & Face-to-face & Civil Servant \\
\hline State 3 & $\mathrm{P} 22$ & M & 44 & Video Call & Civil Servant \\
\hline State 4 & $\mathrm{P} 23$ & M & 42 & Video Call & $\begin{array}{l}\text { Agriculture and } \\
\text { Livestock }\end{array}$ \\
\hline State 5 & $\mathrm{P} 24$ & M & 35 & Face-to-face & Civil Servant \\
\hline State 6 & $\mathrm{P} 25$ & $\mathrm{~F}$ & 36 & Video Call & Inspector \\
\hline
\end{tabular}

The results section summarizes the responses of experts to the predetermined questions and follow-up questions in a semi-structured interview format. Once all interviews were completed, three researchers encrypted the interview forms independently, according to the main subjects: definition, concept and aspects, knowledge and awareness, challenges and barriers, and strategies and suggestions. Researchers also selected the specific expressions in each main subject. Furthermore, these researchers have drawn the frames for SCF. Finally, another researcher controlled the encryption forms and frames and then created the final framework of SCF according to the common findings. This frame can be seen in Figure 2. 


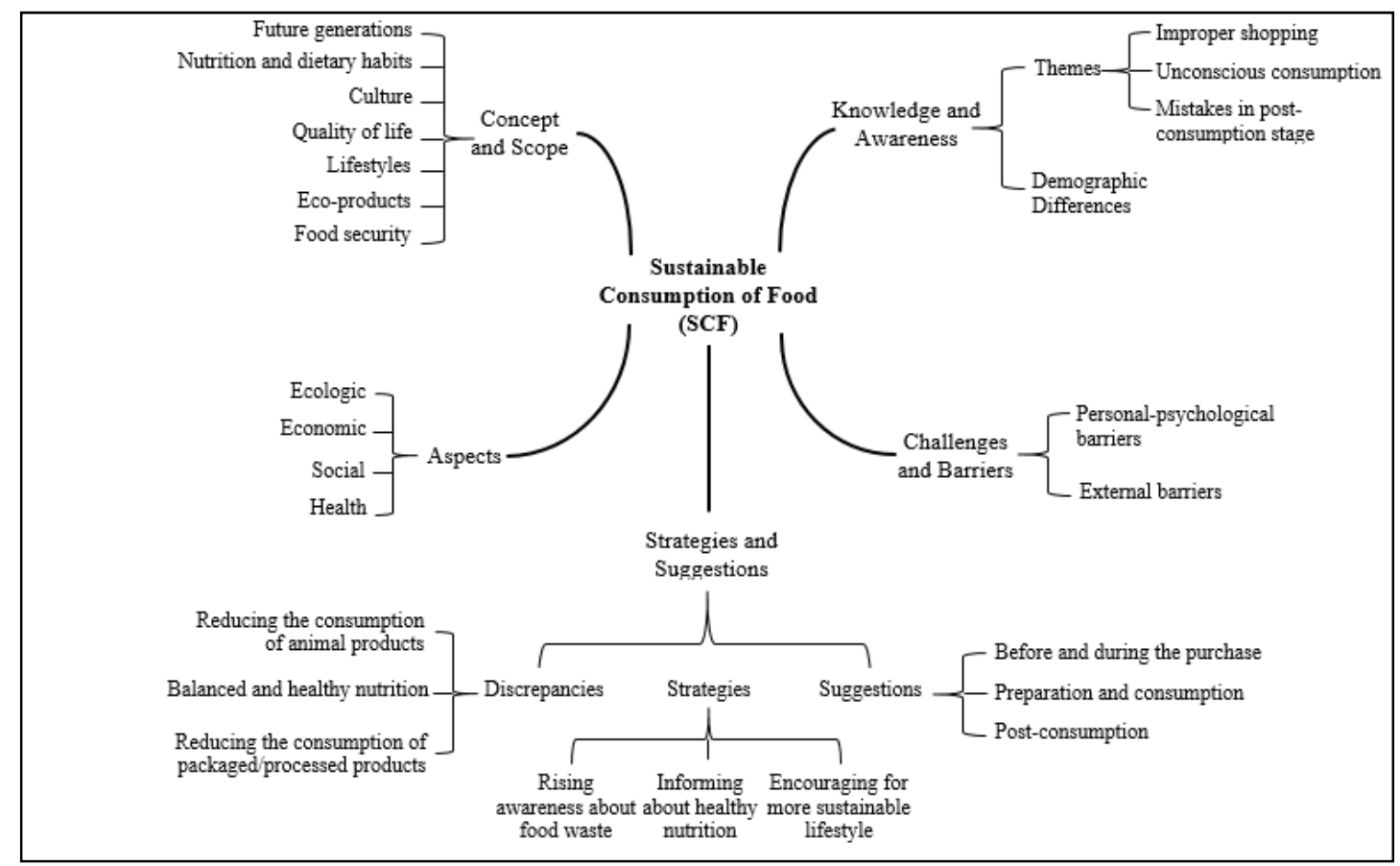

Figure 2. The Framework of Sustainable Consumption of Food (SCF).

\section{Results}

The results consist of four parts: first, we have explored the experts' understanding of the sustainable consumption of food (SCF). Second, experts provided their opinions on consumers' level of knowledge and awareness about the sustainable consumption of food, based on consumers' demographic and social profiles. Third, they formulated the challenges and barriers that hinder consumers' sustainable consumption of food behavior. Fourth, they proposed suggestions on changing consumption habits, recommendations on adults' behavior, and communication strategies for disseminating ideas about more sustainable consumption of food. In the following sections, findings from the interviews with 25 Turkish experts are structured according to the final coding and illustrated by interviewees' specific statements.

\subsection{Definition, Concept, and Aspects of Sustainable Consumption of Food (SCF)}

At the beginning of each individual interview, we invited participants to discuss how they defined the concept of sustainable consumption of food. Participants were allowed to create their own definitions of the concept. This enabled us to reveal the various aspects, dimensions, and scope of the concept. This allowed the concept to be handled and investigated in the widest form by experts. The majority of the interviewed experts represented a shared understanding of SCF as the realization of food consumption in a way that will not harm future generations.

Principles that can ensure that the world population can nourish without harming the ecosystem today and that the next generations can live with a healthy and sufficient diet without having trouble in accessing food.

It is the process of creating consumers, who absorb sustainability at the cultural level in order to leave a cleaner, more livable world to the next generations by converting the wastes arising from the consumption of food as much as possible or making the wastes that cannot be reduced to be reused by recycling. 
Consumption with zero waste philosophy considering the future generations and the status of food sources.

In particular, several interviewees described different ways of SCF; no one associated the concept with excess purchases of food.

It is to reach the food that is provided with hygienic conditions that will provide adequate and balanced nutrition, whenever and wherever it is needed, and to ensure its continuity.

Protection of food from production to consumption.

Balancing production and consumption by using raw materials and natural resources effectively.

Appropriate preparation and consumption of food that is least harmful to the environment.

A waste preventing diet.

Experts emphasized that sustainable food consumption can be realized by changing dietary habits, and that the new habits acquired should be compatible with the culture. There is a need for consumers who have digested the sustainability concept at the cultural level to achieve SCF. Apart from consumption habits and culture, other concepts associated with and included in the scope of SCF were quality of life, lifestyles, and eco-products. More than half of the interviewees mentioned these concepts when identifying SCF. In addition, there is a consensus among experts that SCF also includes the concept of food security, which was mostly defined as ensuring the continuity of consumers' access to healthy, nutritious, safe, and adequate food.

Interviewees classified aspects of SCF in two different ways. A group of experts defined "ecological," "economic," "social," and "health" aspects, while another group divided them further into sub-dimensions, without naming them, and made their explanations accordingly. When interpreting the answers, these two perspectives were evaluated together. Evaluations revealed that the ecological aspects and related issues emerged as the most important aspects by almost all experts (96\%). Important issues related to the ecological aspects of SCF are natural resources and energy use, waste management, the production of carbon footprints, water footprint, the packaging of food (recycled packaging, etc.), positive impacts of consumption of products in season, and local producers' supply on the environment. The environmental impact was generally emphasized by the experts in addition to the ecological effects of food products from the production stage onwards. In fact, it was underlined that SCF started at the production stage. In particular, experts working in the food production departments of agro-based industrial enterprises stated the negative effects of pesticides and harmful chemicals used in the production process. Experts stated that since the environmental impacts of food consumption cannot be cancelled out due to production, procurement processes, and consumption habits, food consumption should be carried out in a way to give the least harm to the environment.

Increasing consumption of local and seasonal foods may be a broad-impact solution for sustainable consumption of food.

The ecologic motivation behind sustainable consumption, according to me, consists of the preference of ecologic foods and the consumption of renewable natural resources and products. 
These are individuals who especially care about the environmentalist perspective, and those who can think of the future of their own children. For example, I can say that individuals expecting a child care more about natural nutrition and pay more attention to environmental problems. Apart from that, I do not think that people from the perspective of "The whole world, the entire universe, all living things exist only for the happiness of people" have sustainable food consumption consciousness.

The ecological aspects of SCF were followed by economic and social aspects. In the context of economic aspects, it is emphasized to make appropriate, better quality, and healthier food products available for a reasonable price for everybody. Moreover, the current imbalance of food distribution and wastage was frequently mentioned. It was stated that the regional development will accelerate, distribution costs will be eliminated, and the cost of the products will decrease with the intensification of purchases from local producers. It is also stated that sustainable food consumption has significant economic effects for all stakeholders involved in food production and consumption processes.

Consumers' preference for packaged food products is effective in decreasing the number of small agricultural businesses and agricultural land. The increase in the number of concrete buildings replacing the agricultural land causes climate change. This problem reveals the effects of unconscious food consumption in the social, economic, and ecological dimensions.

In the social dimension, it is stated that sustainable food consumption processes will create more informed and conscious consumers, which in turn will eliminate the injustice among the societies with high food wastage and the societies that suffer from hunger.

Individual actions on sustainable food consumption can be effective in combating the hunger problem in the world if it is persistent and consistent enough to mobilize public actions. However, if individual movements do not turn into social movements, they are not effective. In this sense, it will be ensured that individual efforts will be transformed into a movement of society and cause changes in food and agriculture policies by influencing policymakers.

(P1, F, 37)

However, none of the participants addressed issues such as fair working conditions (fairness, fair trade, fair payment), individual well-being, societies' development, values, identity-seeking, quality of life, lifestyles, etc. On the dimension of health, participants stated that sustainable food consumption will lead to food safety in the production, harvesting, storage, transportation, processing, and distribution of food. SCF will also enable individuals to have healthy eating habits, healthier generations to emerge, and chronic and nutritional diseases to be reduced.

There should be a change in issues such as consumption of local and seasonal foods, avoiding fast food, decreasing the serving size, increasing the welfare of the society for access to healthy food, balanced nutrition, slow eating, planned shopping, re-utilization, and minimization of waste.

(P14, M, 42)

Vegetable food is the most sustainable food among all types of food, and they have many health benefits in terms of vitamins, minerals, pulp, healthy carbohydrates, and antioxidants. Therefore, consumers should consume natural food products and more vegetable food, which will be effective in reducing the risk of diseases such as cardiovascular diseases, digestive system diseases, and cancer.

SCF would increase the agricultural practices without medicines, reduce the consumption of food products with high environmental impact, and reduce the demand for processed 
products ... all these would have significant positive effects on public health in the long term.

Many of the interviewees specified that the aspects of SCF should be taken into consideration within a comprehensive approach. Experts generally indicated the relation between ecologic and health issues. Although aspects of the concept were asked in the question, the experts made some suggestions additionally in the context of SCF. Besides, the most emphasized suggestions were about the prevention of food waste.

It should be evaluated with its ecological and economic dimensions and with a holistic perspective. The priority should be the ecology dimension. Then the individual should evaluate his economic interaction from a holistic perspective. Continuation of all species without harm should be the main goal.

Reducing the consumption of products that are packaged, processed, and include an additive, which threatens both human health and the environment, is a must.

(P8, F, 55)

Individuals should be aware of the nutrients they need and change their eating habits through balanced and healthy nutrition programs ... the daily share of consumption of both healthy and less environmental impact products like a legume, cereal, fruit, and vegetables can be increased in overall food consumption.

(P16, M, 37)

\subsection{Knowledge and Awareness of Consumers about SCF}

Almost all interviewees stated that the knowledge and awareness levels of adults about SCF were insufficient. Around two-thirds of the interviewees indicated that most adults lack basic knowledge about sustainable consumption. Three themes emerged in the interviewees' discussion about the knowledge of consumers: improper shopping, unconscious consumption, and mistakes in post-consumption behavior. The lack of knowledge about reading labels such as confusing best before dates and expiry dates or thinking that the two are the same, the size of the packaging of the products, not making a shopping list, and unplanned shopping, such as buying more than needed or impulsive buying, were the main indicators of improper shopping. Unplanned shopping is mentioned as the first by 20 of the 25 experts.

Individuals go shopping without planning their purchases and therefore they could buy more than they needed, even products that they don't need at all ... this is actually very basic information, and they have to adapt to their daily life.

... a lot of people buy more food than they can consume and then throw it out ... they are not able to estimate the real amount of food they need, and they do not consider costs for food as very high, so they buy not only rationally but emotionally.

More than $50 \%$ of the interviewees indicated that consumers did not store food products under appropriate conditions or that they did not know the appropriate storage conditions for products. This is the primary statement mentioned in the theme of unconscious consumption. The size of the servings, the lack of time to cook due to intense work pressure, the deterioration of the food products purchased, the expiration of the shelf-life, and the loss and wasting of food during preparation and cooking were stated as other indicators of the lack of knowledge and awareness about SCF.

Unconscious consumption occurs as food loss and waste. Natural resources on earth are limited, and the foods that are over-produced and disposed causes the inefficient use of 
these resources. Also, this causes a negative impact on the environment and climate by polluting the atmosphere and global warming.

I think the level of awareness of adults on this issue is very poor. There are many data supporting this idea. For example, annual bread waste, food waste amounts, obesity frequencies, and results of research studies.

(P23, M, 42)

However, almost half of the interviewees opposed this view and stated that individuals are becoming more conscious day by day and that the positive results of these developments have started to appear. Nevertheless, they stated that the level of consciousness is not too high considering the scope of SCF behavior. For this reason, these seemingly contradictory opinions were evaluated together and gathered in the theme of unconscious consumption.

The level of awareness of adults is increasing day by day, and accordingly, searches for information continue. Nowadays, access to information is very easy, but information pollution is equally high. Therefore, even if the level of consciousness of adults is rapidly increasing, they can acquire wrong consumption habits due to the wrong information they obtain.

(P15, M, 41)

When the current consumption models are examined, we can say that there is an increase in the level of knowledge and awareness thanks to the developments in the field of gastronomy. I can state that there is an increase in the level of consciousness in young adults with progressing age, where the fast food habit is at the forefront.

(P16, M, 37)

The lack of sufficient effort to utilize the remaining products is the most emphasized issue about post-consumption behavior mistakes. Lack of knowledge about composting and re-using of excess foods and the low-level of awareness about sharing foods with people in need were other determinants of mistakes in post-consumption behavior.

Although the experts did not specify sharp differences between social classes, they pointed out the difference between the levels of knowledge and consciousness of consumers with demographically different characteristics. The first comparison was between younger and older adults. There are two points that they have drawn attention to. One of them is the detection of food waste.

Older adults behave more sensitive to avoid waste and try to utilize their products in different ways, as much as possible. However, young adults are not stated as sensitive about waste as older adults.

Young adults have more fast-food habits, and older adults have more cooking and consuming habits at home.

The second subject that demographically compared the adults was related to whether they had children or not. Adults with children are found to seek more information and are more sensitive to food safety, healthy nutrition, production processes of foods, and environmental impacts compared to adults with no children. From the education perspective, it is stated that academic studies are still not sufficient, although they increase the information sources available to consumers. On the other hand, experts have also claimed that unreliable resources on the internet and rumors about SCF are prevalent.

The most important obstacle in this regard is that consumers do not define their bad habits in food consumption as a problem due to their low level of knowledge and awareness about food consumption. Lack of education and especially information pollution caused 
by technological developments (social media, etc.) prevent the consumption habits from changing positively.

... Nutritional ignorance. It is necessary to know what to eat, how much, and what foods to choose.

Fast life and work life in the modern age negatively affect the quality of food and drink. As a result, it is mostly directed toward fast food consumption.

The biggest obstacle is that this issue is not perceived as a problem. Even the awareness that animal food production and consumption is not sustainable at present is not widespread. "What is the benefit of a small step I take? Why would I tire myself?" Unfortunately, this view prevents mass changes.

Our study suggests that, for many experts, there are a variety of obstacles that hinder adults to change their food consumption behavior. Thus, we tried to categorize and identify these challenges and barriers. Accordingly, we classified challenges and barriers as "personal-psychological" and "external barriers." Under the heading of personalpsychological barriers, "being affected by the spread of consumption culture," "the consumption of individuals to socialize," "lack of knowledge about proper nutrition," and "lack of reading habits" are indicated as the prominent issues.

Food consumption is seen as a means of socializing among people. Consumption has now become a piece of our culture. (Popular culture)

Lack of adequate knowledge of family income, health claims on food products, or private labels, logos, and production methods. For example, the prices of organic certified products, UTZ certified products, rainforest certified products are higher due to high certification prices. It is an important obstacle that these products are not consumed by everyone.

Tradition and wannabe psychology in young people lead this. There are advertisements and popular culture in the background of this. In particular, young people should be educated and educated in this regard. I don't think there is another way.

Under the heading of external barriers are: "population growth," "the effect of capitalism," "marketing and advertising policies of enterprises and their effect on consumers," "lack of time to prepare food due to intense work pressure," "lifestyles that lead to rapid and poor-quality food consumption," "household income," and "higher accessibility of foods with negative effects on environment and health obstacles."

Shopping centers encourage people to consume food.

Uncontrolled population growth is one of the biggest obstacles to positive changes in food consumption habits. Unconscious production by producers due to economic concerns reduces the efficiency of natural resources and hinders sustainable food consumption.

(P25, F, 36)

Marketing influence of large companies and global competition... Most foods that have negative effects on health and environment are more economically accessible. That's why I say economic obstacles. 


\subsection{Strategies and Suggestions for SCFs}

Participants were asked to investigate three topics: (1) discrepancies between the recommended food consumption and actual food consumption of adults, (2) strategies to provide SCF and the tools for implementing strategies, and (3) suggestions to make current and future food consumption behavior more sustainable.

Regarding the discrepancies, there are three concepts frequently emphasized by the interviewees. The first one is the need to reduce the consumption of animal food products, which have a high degree of negative impact on the environment, to the minimum levels. Secondly, they emphasized that individuals should change their eating habits and apply balanced nutrition programs that are determined to be in line with the nutrients they need. Thus, the daily share of the consumption of both healthy and lower environmental impact products, such as legumes, cereal, fruit, and other vegetables, can be increased in overall food consumption. Finally, reducing the consumption of products that are packaged, processed, and include an additive, which threatens both human health and the environment, was pointed out. In addition, they stated that there should be a change in issues such as the consumption of local and seasonal foods, avoiding fast food, decreasing the serving size, increasing the welfare of the society for access to healthy food, balanced nutrition, slow eating, planned shopping, re-utilization, and the minimization of waste.

Adults need to decrease the demand for packaged additives. If sustainable foods are considered more expensive than current dietary habits, the solution is undoubtedly to increase the welfare level of societies.

I think that when they reach more information about adequate and balanced nutrition as well as about the production methods of the relevant food and their purchasing power increases, they will tend to change it ... Having a good nutritional knowledge and therefore a nutritional habit; they need to know what, when, and how much they need.

(P2, F, 35)

I think fast food consumption should be avoided. For a balanced diet, individuals should consume not only meat and meat products, but also vegetables, cereals and the required amount of fruits. One must also avoid processed foods.

(P22, M, 44)

I think they should change their way of life. They need to apply the facts they know ... Consumption of local foods, consumption of seasonal foods, and reducing consumption of foods that cause the most damage to the environment (e.g., red meat).

According to the experts, the most significant strategy that makes the current food consumption habits of adults more sustainable is raising awareness about food waste, especially eligible food waste in households. Additionally, more than $70 \%$ of the interviewees emphasized that demonstrating the negative effects of food waste on the environment and giving information to consumers about the nutritional values of the products and the nutrients they need may be listed as feasible strategies. Last, encouraging them to transform lifestyles by enhancing healthy and balanced nutrition such as preferring local foods was defined as an important strategy.

Increasing the level of awareness about food waste, the effects of foods on the environment, the importance of local food, taking part in the concept of sustainable nutrition, ensuring that children grow up with this awareness starting from their kindergartens, and that healthy foods are economically accessible.

First of all, I recommend that they consume local foods for themselves and for a healthy generation. Food consumption should not be overlooked and also waste should be prevented. 
I recommend local farmers and eco-foods, natural farming farmers, to minimize animal food consumption, to increase pulses, vegetables, and fruits and not to consume packaged food ... Additionally, we should develop education materials and disseminate them as much as possible with adults. Even, with the young ones.

I think we should get them to read, research, acquire knowledge and examine the link between consumption and health.

I believe that people should learn about the products and the nutrients (vitamins, etc.) they provide, and the needs of their bodies.

As it can be seen from the clear statements of the interviewees, developing training programs and designing training materials is the most important and practical way to implement strategies to achieve SCF. Thus, education emerges as the primary tool for implementing the mentioned strategies. Families and education policymakers have important tasks in this matter with respect to the experts.

The experts have underlined the importance of communication tools and strategies in order to implement the mentioned strategies and to have a wide range of effects. The most emphasized communication channel that may be used for promoting more sustainable food consumption is social media with a rate of $80 \%$. When considering the frequency of using social media in Turkey by both young and older adults, this is not a surprise. Social media platforms (especially YouTube) may be effective, especially for young adults. Similarly, public service ads were chosen by more than $65 \%$ of the experts. In addition to social media and public service ads, television and other written/visual press and outdoor advertising elements were listed. Academic studies on SCF and seminars were also defined as important tools for the dissemination of true and stimulating information. Furthermore, experts have recommended that informative documents for consumers, which may be presented at food courts and healthy product advertisements through producer and government cooperation, may help to achieve successful results from strategies. A mechanism is needed to control advertisements that encourage waste and unbalanced nutrition. Some interesting suggestions were also identified, such as:

The packages can contain descriptions/instructions on how waste can be used.

(P13, M, 49)

Mobile applications based on gamification can be prepared and presented to people. Suggestions here can help people. But of course, it is necessary to pay attention to a good design and options such as rewards, points, etc. that will motivate people to use this application.

(P1, F, 37)

... Public service ads. Trainings to raise awareness and awareness about sustainable food consumption. Social responsibility projects. Encouraging the sustainability responsibilities of marketing activities and businesses with legal regulations. Awareness raising campaigns and maybe awards on social media.

Despite the strong preference of the experts for increasing awareness and consciousness as well as understanding the environmental impact of food consumption as the foremost issues, consumers should prioritize changing their attitudes and behavior as well. A significant number of the interviewees stated what needs to be undertaken at the stages of food consumption separately. Thus, we categorized the suggestions of the experts in line with the stages of food consumption using the following naming convention: before and during the purchase, during the preparation and consumption, and post-consumption. 
The most emphasized suggestion of the interviewees regarding the behaviors before and during the purchase phase is "planned shopping." They stated that consumers should make a weekly diet plan and buy enough quantities of food products according to this plan. Experts emphasized that weekly plans for shopping are better than a plan for longer-term, and this is both more sustainable and controllable. They also emphasized the need for the water and carbon footprints; in other words, the environment should be taken into consideration when choosing products during shopping. Apart from these, they suggested purchasing local and seasonal products from local producers (e.g., small farmers) to ensure that the products are stored correctly and to gain the habit of reading labels.

Adults should read food packaging and labels and learn about the relevant legal limits, albeit small. Parameters such as nutritional properties and expiration dates of foods should be examined, and packaging should be checked.

Consumers need to be conscious about the production conditions of food and the environmental damage during production before the purchase decision.

Conscious shopping habits should be introduced at the consumer level, awareness about the issue should be increased, the lack of information about efficient food use should be eliminated, appropriate shopping planning should be made, and information should be given on the size of packaging and portion.

... research and purchase of carbon and water footprints of food accordingly, purchase of local and seasonal foods, shopping from these establishments to support small farmers.

Regarding the preparation and consumption phase, experts suggested the preparation of food at appropriate portions according to the number of people, developing the creativity of cooking by making new trials to minimize the waste generated, and keeping the prepared products under the right conditions.

During the preparation, you should make new experiments by focusing on creating benefits for each part.

... during their consumption, they compare the benefits and harm relationships that that food will create for them.

I propose to adults to investigate what happened during the cultivation, production, and packaging stages of the purchased product and to raise awareness of the consumers in this regard.

... I recommend that they act with the awareness of the difficulties of the production stages in food consumption.

One of the main issues targeted in sustainable food consumption is zero waste at the stage of post-consumption. Therefore, appropriate measures should be defined before and during consumption. If there are redundancies, they should be delivered to those in need when they are primarily consumable (e.g., neighbors, municipal houses, social institutions, animal shelters, etc.). However, if they are not consumable, then they should be buried in the soil to take advantage of them as fertilizers or should be disposed of. It is also stated that the municipalities that collect waste have a high duty and responsibility. Additionally, by using these food wastes, energy and fertilizer can be produced, and large economic 
outputs can be provided. It is also mentioned that the packaging materials of packaged food products should be recycled. Finally, some experts expressed that major policies and projects on zero waste in Turkey were carried out in recent times.

... different assessment of food waste (giving to animals etc.)

not only the people's own efforts are enough, but I also encourage people around them to contribute to the process as much as they can.

Many foods that can actually be eaten are thrown away. Before being thrown away, it must be checked whether it can be renewed or not. In addition, the ingredients that remain idle while preparing food should be re-evaluated. For example, the stems of vegetables can be used in many ways. But of course, people should be informed about this first.

... research on reuse of emerging wastes after consumption, re-use instead of disposing to waste or sorting trash for recycling.

... If the remaining food becomes spoiled, composting techniques should be used.

Additionally, purchasing packaged products that are closer to their expiration dates, carrying shopping bags, properly preserving leftovers for future consumption, and preventing over-consumption by serving smaller portions can be considered as contributions to experts' suggestions.

According to the findings, a framework for the sustainable consumption of food is created and presented in Figure 2.

The framework provides a holistic approach to the concept of SCF. The framework consists of five components. Concept and scope deal with the conceptual structure of SCF. This component draws the boundaries of the concept and reveals the general structure of the concept of SCF. It also identifies other similar and related concepts. The aspects of the concept indicate more specifically in which dimensions it is examined. Besides, the SCF concept has four aspects that are relevant. Attitudes affecting the behaviors in the stages of shopping, consumption, and post-consumption and demographic characteristics of the consumers constitute the basis for differences in terms of knowledge and awareness levels about SCF. Thus, knowledge and awareness are the third component of the concept. On the other hand, there are two main obstacles facing consumers in SCF. These can be classified as personal-psychological and external barriers. Lastly, strategies and suggestions have been asserted as the final component of SCF. Discrepancies that need to be addressed, strategies, and suggestions to be developed are presented in the framework. Within the framework, discrepancies have three pillars: reducing the consumption of animal products, balanced and healthy nutrition, and reducing the consumption of packaged processed products. The suggestions are set up in three areas in accordance with the themes. In addition, three generic strategies are identified that should be applied for these suggestions to be successful and create behavior change.

\section{Discussion}

This study addressed the main concepts and scope related to SCF. The prominent concepts are future generations, nutrition and dietary habits, culture, quality of life, lifestyles, eco-products, and food security. Although many of these concepts were discussed in previous studies such as Alsaffar [42] and Vassallo et al. [47], the future generation and leaving a livable world to them are highlighted in this study. With a responsible production pattern, it will be possible to leave healthier and adequate foods for future generations. This study provides a certain theoretical contribution in terms of the aspects of SCF. These aspects 
are consistent with the dimensions of sustainable consumption, which is debated in the literature. We propose four aspects of SCF: ecological, economic, social, and health. This is inconsistent with the previous findings of Pretty et al. [21], Jørgensen et al. [23], Wolff and Schönherr [25], Zhao and Schroeder [26], and Lee [27], none of which identify "health" as a dimension. As opposed to Pretty et al. [21] and Zhao and Schroeder [26], our findings do not support a political dimension as part of the framework we proposed. Among all, experts asserted that the ecological aspect is the most remarkable one, and it includes many sub-dimensions such as use of energy and natural resources, waste management, footprints, and packaging. This is consistent with the previous findings of Pretty et al. [21], Lee [27] and Vermeir and Verbeke [30], except for Zhao and Schroeder [26], who do not consider an ecological aspect.

Our findings have shown that there is a lack of knowledge and awareness about the sustainable consumption of food. The reason for this is that adults do not see this as a problem, and those who are aware of this problem cannot access sufficient and reliable sources of information. In accordance, we defined three themes, which refer to the background of the unsustainable behavior of consumers. These are improper shopping, unconscious consumption, and mistakes during the post-consumption stage. Our findings show that two-third of experts have pointed out the need for education about fundamental knowledge even regarding basic issues. For instance, not making shopping lists and the impulse buying of food, improper storage conditions, and avoiding oversized servings can be counted as skills and behaviors that need to be improved. We agree with Heiskanen et al. [64] in highlighting the need for education as the most significant factor to achieve sustainable behavior. Additionally, the demographic component of knowledge and the awareness level of consumers have been discussed and listed in this study. According to our findings, the gender difference is not significant, in contradiction to Azzurra et al. [51], Kottala and Singh [52], and Vermeir and Verbeke [53]. In terms of age, older people exhibit more sustainable behavior, such as eating at home and preventing food waste. This finding is in line with Verain et al. [54], but it is opposed to Azzurra et al. [51] with no consensus reached. Contributing to the literature, we have asserted that families with children are more sensitive about the sustainable consumption of food.

Our findings about the barriers on adopting SCF are in line with Tobler et al. [61], Chakrabarti [69], Chakrabarti and Baisya [70], Hughner et al. [71], Vittersø and Tangeland [72], and Yadav et al. [73]. However, from the perspective of challenges and barriers, we classified barriers into two groups: personal-psychological and external barriers. The most important obstacles defined as internals are social norms, such as being affected by a consumption culture and consumption for socializing. Nevertheless, population growth, the rising number of marketing and advertising efforts of companies, and lack of time were listed by the experts as the determinants of external barriers.

Finally, strategies and suggestions for more sustainable consumption of food were investigated. Reducing the consumption of animal products and packaged products versus balanced and healthy nutrition are the factors that were underlined by the experts as the difference between the actual and recommended consumption of food. This is consistent with Verain et al. [54] and Wiedmann et al. [77]. Furthermore, three stages of food consumption (before and during the purchase, preparation and consumption, and post-consumption) were associated with the experts' suggestions. Many specific suggestions were identified in each stage from the fundamental to the advanced. For instance, experts suggested reading the labels of foods during shopping as a fundamental behavior of consumers and fertilizing from food waste to gain economic outputs as an advanced level effort that can be accomplished under the coordination of consumers and local governments. For individual efforts to produce expected positive results and needs to be transformed into a mass movement, public policies should play a regulatory and mobilizing role. 


\section{Conclusions}

The sustainable consumption of food is a critical issue for consumers, industry, and the public. With the exponential growth of attention toward sustainability, existing studies in the field of the sustainable consumption of food are generally focused on consumers attitudes and behavior. Thus, unlike the previous studies, this paper is built based on the opinions of experts from various fields including academics, NGO managers, public representatives, and professionals from the food industry. Moreover, this study aims to reveal a framework that includes all components of SCF. To do this, data were collected from 25 experts via in-depth interviews, and some of the findings are highlighted. The main conclusion of this study is to exhibit a framework that provides a holistic approach to SCF. The framework includes the experts' perception about the SCF concept and the scope, aspects, consumers' knowledge, and awareness about SCF, together with the challenges and barriers. Moreover, this study points out some specific strategies and suggestions for providing more sustainable consumption of food.

To implement these suggestions, we have identified three key strategies: raising awareness, informing consumers about healthy nutrition, and encouraging a sustainable lifestyle. It will be possible to increase the level of knowledge and awareness about SCF by organizing various training on all aspects. Effective communication should be created using contemporary communication channels, such as social media, public service announcements, and new and interactive technologies, including webinars as well as traditional channels such as informative brochures. Relevant public institutions and organizations, universities, academicians, social organizations, and consumers should work in collaboration to achieve the sustainable consumption of food. In addition, policy makers can make regulations for both consumers and producers/sellers. For instance, additional taxes can be levied on unsafe foods for consumers. Additionally, public service ads prepared and presented by public authorities may drive consumers to pay more attention to reading labels and acting accordingly. On the other side, less or recycled packaging can be supported with grants by governments.

Considering food waste, authorities may apply policies to reduce or organize overconsumption. For example, excess foods can be collected from restaurants, food suppliers, etc., and distributed to those who need them or an organization could be created to recycle or reuse. These collected foods can be used in feeding animals or converted into another form of food (for example, tomatoes to gravy) or things such as fertilizers. From a longterm perspective, to make consumer behavior more sustainable, policymakers or public authorities may play significant roles in establishing agro-food networks and consumer cooperatives. Moreover, policymakers have a responsibility to organize related groups such as universities, NGOs, industry representatives, and consumer associations to determine effective policies and implications to support sustainable lifestyles.

There is a remarkable limitation in generalizing the findings of this study. This study is built on the opinions of the experts and ignores the view of consumers. In further studies, the opinions of consumers need to be explored and evaluated in line with these findings. Additionally, because we used snowball sampling, community bias can occur. Although sampling has been started by selecting samples from four different fields of expertise in order to avoid the community bias that may arise due to the nature of snowball sampling, this bias can be prevented further by reaching a higher number of experts from each field in future studies. In addition, different experts from other countries could be involved, cultural diversities could be explored and different demographic characteristics and fields of expertise could be considered for a more comprehensive point of view.

Author Contributions: Conceptualization, F.T.Ö. and Z.A.B.; Data curation, O.D.; Formal analysis, O.D. and Z.A.B.; Investigation, F.T.Ö., M.G.D. and Z.A.B.; Methodology, Z.A.B.; Resources, M.G.D.; Writing-original draft, M.G.D., O.D. and Z.A.B.; Writing—review and editing, R.H. All authors have read and agreed to the published version of the manuscript. 
Funding: This work was supported by the Turkish National Agency within the Erasmus+ Project (2018-1-TR01-KA204-058739).

Institutional Review Board Statement: Not applicable.

Informed Consent Statement: Informed consent was obtained from all subjects involved in the study.

Data Availability Statement: The data will be made available on request from the corresponding author. Conflicts of Interest: The authors declare no conflict of interest.

\section{References}

1. United Nations. Sustainable Development Goals Report 2018. Available online: https://unstats.un.org/sdgs/report/2018 (accessed on 4 March 2019).

2. United Nations. Transforming Our World: The 2030 Agenda for Sustainable Development. Available online: https://sdgs.un.or g/2030agenda (accessed on 12 September 2018).

3. EEA (European Economic Area). Per Capita EU-27 Consumption of Meat, Fish and Dairy (by Weight). Available online: https:/ / www.eea.europa.eu/data-and-maps/daviz/per-capita-eu-27-consumption-1\#tab-chart_1 (accessed on 18 September 2018).

4. Kummu, M.; De Moel, H.; Porkka, M.; Siebert, S.; Varis, O.; Ward, P.J. Lost Food, Wasted Resources: Global Food Supply Chain Losses and Their Impacts on Freshwater, Cropland, and Fertiliser Use. Sci. Total Environ. 2012, 438, 477-489. [CrossRef]

5. Rogissart, L.; Foucherot, C.; Bellassen, V. Estimating Greenhouse Gas Emissions from Food Consumption: Methods and Results. Institute for Climate Economics, February. Available online: https://www.i4ce.org/wp-core/wp-content/uploads/2019/03/03 18-I4CE2984-EmissionsGES-et-conso-alimentaire-Note-20p-VA_V2.pdf (accessed on 11 May 2019).

6. Sandström, V.; Valin, H.; Krisztin, T.; Havlík, P.; Herrero, M.; Kastner, T. The Role of Trade in the Greenhouse Gas Footprints of EU Diets. Glob. Food Secur. 2018, 19, 48-55. [CrossRef]

7. Barrett, J.; Scott, K. Link Between Climate Change Mitigation and Resource Efficiency: A UK Case Study. Glob. Environ. Chang. 2012, 22, 299-307. [CrossRef]

8. EC (European Commission), Joint Research Centre, Institute for Environment and Sustainability. ILCD Handbook, Analysis of Existing Environmental Impact Assessment Methodologies for Use in Life Cycle Assessment, 1st ed.; EC-JRC: Ispra, Italy, 2010. Available online: http:/ / lct.jrc.ec.europa.eu (accessed on 21 July 2020).

9. Coff, C.; Korthals, M.; Barling, D. Ethical Traceability and Informed Food Choice. In Ethical Traceability and Communicating Food; Coff, C., Barling, D., Korthals, M., Nielsen, T., Eds.; Springer: Dordrecht, The Netherlands, 2008; Volume 15, pp. 1-18. [CrossRef]

10. Millstone, E.; Lang, T. The Atlas of Food. Appropr. Technol. 2003, 30, 63-64.

11. Reisch, L.; Eberle, U.; Lorek, S. Sustainable Food Consumption: An Overview of Contemporary Issues and Policies. Sustain. Sci. Pract. Policy 2013, 9, 7-25. [CrossRef]

12. Barilla Center for Food and Nutrition (BFCN). Double Pyramid 2012: Enabling Sustainable Food Choices. Available online: www.barilla.com (accessed on 25 June 2019).

13. Hamilton, C.; Denniss, R.; Baker, D. Wasteful Consumption in Australia; Discussion Paper 77; The Australian Institute: Canberra, Australia, 2005.

14. Lyndhurst, B. Food Behaviour Consumer Research —Findings from the Quantitative Survey; WRAP Briefing Paper; WRAP: Banbury, UK, 2007.

15. Stefan, V.; van Herpen, E.; Tudoran, A.A.; Lähteenmäki, L. Avoiding Food Waste by Romanian Consumers: The Importance of Planning and Shopping Routines. Food Qual. Prefer. 2013, 28, 375-381. [CrossRef]

16. Watson, M.; Meah, A. Food, Waste and Safety: Negotiating Conflicting Social Anxieties into the Practices of Domestic Provisioning. Sociol. Rev. 2012, 60, 102-120. [CrossRef]

17. Ayala, N.M. Sustainable Consumption, the Social Dimension. Rev. Ecuat. Med. Cienc. Biol. 2018, 39. [CrossRef]

18. Barilla Center for Food and Nutrition (BFCN). A Global Study on Nutrition Agriculture and Food Waste. Available online: www.foodsustainability.eiu.com (accessed on 2 January 2020).

19. Republic of Turkey, Ministry of Agriculture and Forestry. Strategic Plan, 2013-2017. Available online: https://www.tarimorman .gov.tr/SGB/Belgeler/Stratejik\%20Plan\%202013-2017.pdf (accessed on 1 August 2019).

20. Nkamnebe, A.D. Sustainability Marketing in the Emerging Markets: Imperatives, Challenges, and Agenda Setting. Int. J. Emerg. Mark. 2011, 6, 217-232. [CrossRef]

21. Pretty, J.; Ball, A.; Benton, T.; Guivant, J.; Lee, D.R.; Orr, D.; Pfeffer, M.; Ward, H. The SAGE Handbook of Environment and Society; Sage: London, UK, 2007; 640p.

22. WCED (World Commission on Environment and Sustainable Development). Our Common Future (The Brundtland Report); Oxford University Press: Oxford, UK, 1987; Volume 17, pp. 1-91.

23. Jørgensen, A.; Le Bocq, A.; Nazarkina, L.; Hauschild, M. Methodologies for Social Life Cycle Assessment. Int. J. Life Cycle Assess. 2008, 13, 96. [CrossRef]

24. Perlas, N. Overcoming Illusions About Biotechnology; Zed Books: London, UK, 1994; 120p. 
25. Wolff, F.; Schönherr, N. The Impact Evaluation of Sustainable Consumption Policy Instruments. J. Consum. Policy 2011, 34, 43-66. [CrossRef]

26. Zhao, W.; Schroeder, P. Sustainable Consumption and Production: Trends, Challenges and Options for the Asia-Pacific Region. Nat. Resour. Forum 2010, 34, 4-15. Available online: https:/ / onlinelibrary.wiley.com/doi/epdf/10.1111/j.1477-8947.2010.01275.x (accessed on 2 January 2020). [CrossRef]

27. Lee, K. Predictors of Sustainable Consumption Among Young Educated Consumers in Hong Kong. J. Int. Consum. Mark. 2014, 26, 217-238. [CrossRef]

28. Kymäläinen, T.; Seisto, A.; Malila, R. Generation Z Food Waste, Diet and Consumption Habits: A Finnish Social Design Study with Future Consumers. Sustainability 2021, 13, 2124. [CrossRef]

29. Jones, P.; Hillier, D.; Comfort, D. In the Public Eye: Sustainability and the UK's Leading Retailers. J. Public Aff. 2013, 13, 33-40. [CrossRef]

30. Bălan, C. How Does Retail Engage Consumers in Sustainable Consumption? A Systematic Literature Review. Sustainability 2021, 13, 96. [CrossRef]

31. Vermeir, I.; Verbeke, W. Sustainable Food Consumption Among Young Adults in Belgium: Theory of Planned Behaviour and the Role of Confidence and Values. Ecol. Econ. 2008, 64, 542-553. [CrossRef]

32. Wongprawmas, R.; Mora, C.; Pellegrini, N.; Guiné, R.P.F.; Carini, E.; Sogari, G.; Vittadini, E. Food Choice Determinants and Perceptions of a Healthy Diet among Italian Consumers. Foods 2021, 10, 318. [CrossRef]

33. Quoquab, F.; Mohammad, J. Managing Sustainable consumption: Is it a problem or panacea? In Sustainable Economic Development; Leal Filho, W., Pociovalisteanu, D.M., Al-Amin, A., Eds.; Springer International Publishing: Geneva, Switzerland, 2017 ; pp. 115-125. [CrossRef]

34. Austgulen, M.H. Environmentally Sustainable Meat Consumption: An Analysis of the Norwegian Public Debate. J. Consum. Policy 2014, 37, 45-66. [CrossRef]

35. Clonan, A.; Wilson, P.; Swift, J.A.; Leibovici, D.G.; Holdsworth, M. Red and Processed Meat Consumption and Purchasing Behaviours and Attitudes: Impacts for Human Health, Animal Welfare and Environmental Sustainability. Public Health Nutr. 2015, 18, 2446-2456. [CrossRef]

36. de Bakker, E.; Dagevos, H. Reducing Meat Consumption in Today's Consumer Society: Questioning the Citizen-consumer Gap. J. Agric. Environ. Ethics 2012, 25, 877-894. [CrossRef]

37. Vinnari, M. The Future of Meat Consumption-Expert Views from Finland. Technol. Forecast. Soc. Chang. 2008, 75, 893-904. [CrossRef]

38. Thøgersen, J. Country Differences in Sustainable Consumption: The Case of Organic Food. J. Macromarketing 2010, 30, 171-185. [CrossRef]

39. Nguyen, H.V.; Nguyen, N.; Nguyen, B.K.; Greenland, S. Sustainable Food Consumption: Investigating Organic Meat Purchase Intention by Vietnamese Consumers. Sustainability 2021, 13, 953. [CrossRef]

40. Collins, A.; Fairchild, R. Sustainable Food Consumption at a Sub-national Level: An Ecological Footprint, Nutritional and Economic Analysis. J. Environ. Policy Plan. 2007, 9, 5-30. [CrossRef]

41. Gorissen, K.; Weijters, B. The Negative Footprint Illusion: Perceptual Bias in Sustainable Food Consumption. J. Environ. Psychol. 2016, 45, 50-65. [CrossRef]

42. Alsaffar, A.A. Sustainable Diets: The Interaction Between Food Industry, Nutrition, Health and the Environment. Food Sci. Technol. Int. 2016, 22, 102-111. [CrossRef] [PubMed]

43. Duchin, F. Sustainable Consumption of Food: A Framework for Analyzing Scenarios About Changes in Diets. J. Ind. Ecol. 2005, 9 , 99-114. [CrossRef]

44. Friel, S.; Barosh, L.J.; Lawrence, M. Towards Healthy and Sustainable Food Consumption: An Australian Case Study. Public Health Nutr. 2014, 17, 1156-1166. [CrossRef] [PubMed]

45. Meybeck, A.; Gitz, V. Sustainable Diets within Sustainable Food Systems. Proc. Nutr. Soc. 2017, 76, 1-11. [CrossRef]

46. Robinson, R.; Smith, C. Psychosocial and Demographic Variables Associated with Consumer Intention to Purchase Sustainably Produced Foods as Defined by the Midwest Food Alliance. J. Nutr. Educ. Behav. 2002, 34, 316-325. [CrossRef]

47. Vassallo, M.; Scalvedi, M.L.; Saba, A. Investigating Psychosocial Determinants in Influencing Sustainable Food Consumption in Italy. Int. J. Consum. Stud. 2016, 40, 422-434. [CrossRef]

48. Barling, D. The Challenges Facing Contemporary Food Systems: European Policy and Governance Pathways to Sustainable Food Consumption and Production. Agron. Environ. Soc. 2011, 1, 15-25.

49. Grunert, S.C.; Juhl, H.J. Values, Environmental Attitudes, and Buying of Organic Foods. J. Econ. Psychol. 1995, 16, 39-62. [CrossRef]

50. Kamenidou, I.C.; Mamalis, S.A.; Pavlidis, S.; Bara, E.-Z.G. Segmenting the Generation Z Cohort University Students Based on Sustainable Food Consumption Behavior: A Preliminary Study. Sustainability 2019, 11, 837. [CrossRef]

51. Azzurra, A.; Massimiliano, A.; Angela, M. Measuring Sustainable Food Consumption: A Case Study on Organic Food. Sustain. Prod. Consum. 2019, 17, 95-107. [CrossRef]

52. Kottala, S.Y.; Singh, R. A Review of Sustainability, Deterrents, Personal Values, Attitudes and Purchase Intentions in the Organic Food Supply Chain. Pac. Sci. Rev. B Hum. Soc. Sci. 2015, 1, 114-123. [CrossRef] 
53. Vermeir, I.; Verbeke, W. Sustainable Food Consumption: Exploring the Consumer "Attitude-behavioral Intention" Gap. J. Agric. Environ. Ethics 2006, 19, 169-194. [CrossRef]

54. Verain, M.C.; Dagevos, H.; Antonides, G. Sustainable Food Consumption. Product Choice or Curtailment? Appetite 2015, 91, 375-384. [CrossRef]

55. de Barcellos, M.D.; Krystallis, A.; de Melo Saab, M.S.; Kügler, J.O.; Grunert, K.G. Investigating the Gap Between Citizens' Sustainability Attitudes and Food Purchasing Behaviour: Empirical Evidence from Brazilian Pork Consumers. Int. J. Consum. Stud. 2011, 35, 391-402. [CrossRef]

56. Bulut, Z.A.; Özkaya, F.T.; Karabulut, A.N.; Atağan, G. Gıda Ürünlerinin Sürdürülebilir Tüketimi Bağlamında Tüketici Tipolojisi Geliştirme Çalışması. Çukurova Üniversitesi Sosyal Bilimler Enstitüsü Dergisi 2019, 28, 73-90. [CrossRef]

57. Öberg, C.; Huge-Brodin, M.; Björklund, M. Applying a Network Level in Environmental Impact Assessments. J. Bus. Res. 2012, 65, 247-255. [CrossRef]

58. Von Blottnitz, H.; Curran, M.A. A Review of Assessments Conducted on Bio-ethanol as a Transportation Fuel from a Net Energy, Greenhouse Gas, and Environmental Life Cycle Perspective. J. Clean. Prod. 2007, 15, 607-619. [CrossRef]

59. Bailey, R.; Froggatt, A.; Wellesley, L. Livestock-Climate Change's Forgotten Sector. Research Paper. Chatham House. Available online: https:/ / www.chathamhouse.org/sites/default/files/field/field_document/20141203LivestockClimateChangeForgot tenSectorBaileyFroggattWellesleyFinal.pdf (accessed on 2 January 2020).

60. Lea, E.; Worsley, A. Benefits and Barriers to the Consumption of a Vegetarian Diet in Australia. Public Health Nutr. 2003, 6 , 505-511. [CrossRef]

61. Tobler, C.; Visschers, V.H.; Siegrist, M. Eating Green. Consumers' Willingness to Adopt Ecological Food Consumption Behaviors. Appetite 2011, 57, 674-682. [CrossRef] [PubMed]

62. Truelove, H.B.; Parks, C. Perceptions of Behaviors that Cause and Mitigate Global Warming and Intentions to Perform These Behaviors. J. Environ. Psychol. 2012, 32, 246-259. [CrossRef]

63. Vanhonacker, F.; Van Loo, E.J.; Gellynck, X.; Verbeke, W. Flemish Consumer Attitudes Towards More Sustainable Food Choices. Appetite 2013, 62, 7-16. [CrossRef]

64. Heiskanen, E.; Brohmann, B.; Schönherr, N.; Aalto, K. Policies to Promote Sustainable Consumption: Framework for a Futureoriented Evaluation. Prog. Ind. Ecol. Int. J. 2009, 6, 387-403. [CrossRef]

65. Hoekstra, A.Y. Water Neutral: Reducing and Offsetting the Impacts of Water Footprints, Value of Water Research Report Series No. 28. Available online: https://www.waterfootprint.org/media/downloads/Report28-WaterNeutral.pdf (accessed on 4 February 2021).

66. Herva, M.; Franco, A.; Carrasco, E.F.; Roca, E. Review of Corporate Environmental Indicators. J. Clean. Prod. 2011, 19, 1687-1699. [CrossRef]

67. Galli, A.; Wiedmann, T.; Ercin, E.; Knoblauch, D.; Ewing, B.; Giljum, S. Integrating Ecological, Carbon and Water Footprint into a "Footprint Family" of Indicators: Definition and Role in Tracking Human Pressure on the Planet. Ecol. Indic. 2012, 16, 100-112. [CrossRef]

68. Mason, M.; Zeitoun, M. Questioning Environmental Security. Georg. J. 2013, 179, 294-297. [CrossRef]

69. Chakrabarti, S. Factors Influencing Organic Food Purchase in India-Expert Survey Insights. Br. Food J. 2010. [CrossRef]

70. Chakrabarti, S.; Baisya, R.K. Purchase Motivations and Attitudes of Organic Food Buyers. Decision 2007, $34,1-22$.

71. Hughner, R.S.; McDonagh, P.; Prothero, A.; Shultz, C.J.; Stanton, J. Who Are Organic Food Consumers? A Compilation and Review of Why People Purchase Organic Food. J. Consum. Behav. Int. Res. Rev. 2007, 6, 94-110. [CrossRef]

72. Vittersø, G.; Tangeland, T. The Role of Consumers in Transitions Towards Sustainable Food Consumption. The Case of Organic Food in Norway. J. Clean. Prod. 2015, 92, 91-99. [CrossRef]

73. Yadav, R.; Singh, P.K.; Srivastava, A.; Ahmad, A. Motivators and Barriers to Sustainable Food Consumption: Qualitative Inquiry About Organic Food Consumers in a Developing Nation. Int. J. Nonprofit Volunt. Sect. Mark. 2019, 24, e1650. [CrossRef]

74. Sidali, K.L.; Spiller, A.; von Meyer-Hoefer, M. Consumer Expectations Regarding Sustainable Food: Insights from Developed and Emerging Markets. Int. Food Agribus. Manag. Rev. 2016, 19, 141-170.

75. Gorgitano, M.T.; Sodano, V. Sustainable Food Consumption: Concept and Policies. Calitatea 2014, 15, 207.

76. Aschemann-Witzel, J.; De Hooge, I.; Amani, P.; Bech-Larsen, T.; Oostindjer, M. Consumer-related Food Waste: Causes and Potential for Action. Sustainability 2015, 7, 6457-6477. [CrossRef]

77. Wiedmann, K.-P.; Hennigs, N.; Behrens, S.H.; Klarmann, C. Tasting Green: An Experimental Design for Investigating Consumer Perception of Organic Wine. Br. Food J. 2014. [CrossRef]

78. Siegrist, M.; Visschers, V.H.; Hartmann, C. Factors Influencing Changes in Sustainability Perception of Various Food Behaviors: Results of a Longitudinal Study. Food Qual. Prefer. 2015, 46, 33-39. [CrossRef]

79. Byerly, H.; Balmford, A.; Ferraro, P.J.; Hammond Wagner, C.; Palchak, E.; Polasky, S.; Ricketts, T.H.; Schwartz, A.J.; Fisher, B. Nudging Pro-environmental Behavior: Evidence and Opportunities. Front. Ecol. Environ. 2018, 16, 159-168. [CrossRef]

80. Guthrie, J.; Mancino, L.; Lin, C.-T.J. Nudging Consumers Toward Better Food Choices: Policy Approaches to Changing Food Consumption Behaviors. Psychol. Mark. 2015, 32, 501-511. [CrossRef]

81. United Nations Environment Programme. Food Waste Index Report 2021. Nairobi. Available online: https://www.unep.org/res ources / report/ unep-food-waste-index-report-2021 (accessed on 17 March 2021). 
82. TEPGE. Tarım Ürünleri Piyasaları. Available online: https://arastirma.tarimorman.gov.tr/tepge/Menu/27/Tarim-Urunleri-Piy asalari (accessed on 16 January 2021).

83. TZOB. Ekmek, Sebze ve Meyveyle Doyuyoruz. Available online: https://www.tzob.org.tr/basin-odasi/haberler/ekmek-sebze-v e-meyveyle-doyuyoruz\%E2\%80\%A6 (accessed on 22 March 2019).

84. Doğan, N. TRA1 Bölgesinde (Erzurum, Erzincan, Bayburt) Hanelerin Kırmızı Et, Tavuk Eti ve Balık Eti Tüketimine Yönelik Mevcut Durum Üzerine Bir Araştırma. Türk Tarım ve Doğa Bilimleri Dergisi 2019, 6, 285-295. [CrossRef]

85. Bräutigam, K.-R.; Jörissen, J.; Priefer, C. The extent of food waste generation across EU-27: Different calculation methods and the reliability of their results. Waste Manag. Res. 2014, 32, 683-694. [CrossRef] [PubMed]

86. Schanes, K.; Dobernig, K.; Gözet, B. Food waste matters-A systematic review of household food waste practices and their policy implications. J. Clean. Prod. 2018, 182, 978-991. [CrossRef] 